\title{
Editorial
}

\section{Neovascularisation again}

Since the original suggestion by Michaelson in 1948 that there is probably a substance in retina which can stimulate new vessel formation' and the publications from Ashton's laboratory explaining the preretinal neovascularisation in retinopathy of prematurity $(\mathrm{ROP})^{2}$ and the more remote neovascularisation of the iris in central retinal vein occlusion $(\mathrm{CRVO})^{3}$ in terms of retinal hypoxia, many experiments have been carried out in attempts to elucidate the mechanisms involved. The probability that the hypoxia theory is correct was much increased by the classical work of Laatikainen and Kohner, ${ }^{4}$ who showed that neovascularisation occurred in CRVO only when retinal capillary closure could be identified by fluorescein angiography. Meanwhile the search for a substance to incriminate had already begun. Numerous clinical studies were carried out over the years, not to mention the rise of retinal ablation as a means of treatment for diabetic retinopathy ${ }^{5}$ and neovascular glaucoma. ${ }^{6}$

One of the earliest substances to come under suspicion was lactic acid. ${ }^{7}$ Intravitreal injections of lactic acid were given repeatedly to young kittens, of which $50 \%$ developed intravitreal vasoproliferation. Later attempts to confirm this by demonstrating excess lactic acid in the vitreous of kittens and rats whose retinas had been rendered ischaemic were unsuccessful, ${ }^{8}$ and lactic acid seems to have been dropped. In 1978 Patz and coworkers ${ }^{9}$ made the interesting observation that tumour cells introduced into rabbit vitreous produced neovascularisation only when in contact with vascularised retina and suggested that there may normally be an antineovascularising substance present in rabbit vitreous. It is worth mentioning that as well as studies on the subject of preretinal intravitreal and even iris new vessels interest was also being taken in subretinal neovascularisation, since this is just as important a field as the others and probably concerned with similar pathological processes. Miller and colleagues, ${ }^{10}$ for example, thought that the retinal pigment epithelium might play a part in inhibiting new formed subretinal vessels, but, although there does not seem to be a convincing theory as to the causation of subretinal neovascularisation, nevertheless the possibility that the pigment epithelium has some sort of active role has continued to arouse interest.

There was something of a setback in 1977 when Kissun and Garner $^{11}$ were unable to prove that extracts of ischaemic kitten retina would induce excess neovascularisation in experimental corneal tunnels, but in 1980 Federman and coworkers ${ }^{12}$ succeeded in inducing corneal vascularisation by retinal implants, and in $1982 \mathrm{Kissun}$ and colleagues ${ }^{13}$ found similar results in chorioallantoic membrane test beds using extracts of healthy adult cat retina. They proposed a low molecular weight angiogenic factor, which seems to be similar or possibly the same as the endothelial cell stimulating angiogenic factor (ESAF) which was originally described in tumour angiogenesis. They pointed out that, whereas clinically neovascularisation seems to occur only in response to retinal ischaemia, the angiogenic factor appears to be present in healthy retina. This puzzle can be explained by postulating that there is also an antivascularising substance present which is normally in equilibrium with ESAF. Neovascularisation in disease or regression of neovascularisation as a result of therapy may therefore be expressions of alterations in this balance rather than the production or reduction of a single substance. In 1986 Taylor and coworkers carried the story further when they demonstrated significant levels of an ESAF-like substance in the retinas of oxygen deprived kittens ${ }^{1+}$ and in 1988 increased levels in the vitreous humour. ${ }^{\text {is }}$

Parallel with these studies have been tissue culture experiments where the properties of retinal extracts can be studied in the laboratory in rather a precise and elegant manner. Wong and colleagues ${ }^{16}$ have shown that tissue-culture media conditioned by extracts of retinal pigment epithelial cells stimulate the proliferation of retinal capillary endothelial cells as well as pericytes. However, in a paper in the $B F O$ this month Singh and colleagues show that exactly the opposite effects are seen in tissue culture when the system is conditioned by vitreous from eyes which had been subjected to extensive retinal destruction by laser. This appears to be further evidence for the retina's balancing act between neovascularisation and vascular stability, and the authors proffer it as a possible explanation for the beneficial antineovascularising effect of retinal ablation.

\section{REDMOND SMITH}

1 Michaelson IC. The mode of development of the vascular system of the retina, with some observations on its significance for certain retinal diseases. Trans Ophthalmol Soc UK 1948; 68: 137-80.

2 Ashton N, Ward B, Serpell G. Effect of oxygen on developing retinal vessels with particular reference to the problem of retrolental fibroplasia. $\mathrm{Br} \mathcal{F}$ Ophthalmol 1954; 38: 397-432.

3 Smith RJH. Thombotic glaucoma; a clinico-pathological study. 17th Cong Ophthal Internat (1954). Toronto: University of Toronto Press, 1955: 2: 1164 75.

4 Laatikainen L, Kohner EM. Fluorescein angiography and its prognostic significance in central retinal vein occlusion. BrF Ophthalmol 1976; 60:411-8. 5 Meyer-Schwickerath G. Treatment of Eales' disease and diabetic retinopathy with photocoagulation. Trans Ophthalmol Soc UK 1964; 84: 67-76.

6 Smith RJH. Neovascularisation in ocular disease. Trans Ophthalmol Soc UK 1961; 81: $125-44$.

7 Imre G. Studies on the mechanism of retinal neovascularisation: role of lactic acid. Brf Ophthalmol 1964; 48: 75-82.

8 Gerke E, Spitznas M, Brodde OE The role of lactic acid in retinal neovascularisation. Graefes Arch Clin Exp Ophthalmol 1976; 200: 79-84.

9 Patz A, Brem S, Finkelstein D, et al. A new approach to the problem of retinal neovascularisation. Ophthalmology 1978; 85: 626-37.

10 Miller H, Miller B, Ryan SJ. The role of retinal pigment epithelium (RPE) in involution of subretinal neovascularisation. Invest Ophthalmol Vis Sci 1986; 27: $1644-52$

11 Kissun RD, Garner A. Vasoformative properties of normal and hypoxic retinal tissue. Br J Ophthalmol 1977; 61: 394-8.

12 Federman JL, Brown GC, Felberg NT, Felton SM. Experimental ocular angiogenesis. Am f Ophthalmol 1980; 89: 231-7.

13 Kissun RD, Hill CR, Garner A, Phillips P, Kumar S, Weiss JB. A low molecular weight angiogenic factor in cat retina. $\mathrm{Br} \mathcal{F}$ Ophthalmol 1982; 66: $165-9$.

14 Taylor CM, Weiss JB, Kissun RD, Garner A. Effect of oxygen tension on the quantities of procollagenase-activating angiogenic factor present in the quantities of procollagenase-activating angiogenic factor
developing kitten retina. Brf Ophthalmol 1986; 70: 162-5.

15 Taylor CM, Weiss JB, Kissun RD, Garner A. Increased procollagenase activating factor in the vitreous humour of oxygen-treated kittens. $\mathrm{Br} \mathcal{F}$ Ophthalmol 1988; 72: 2-4.

16 Wong HC, Boulton ME, Clark P, Bayly M, Marshall J. Retinal pigment epithelial cells produce mitogenic factors for retinal microvascular cells in culture: a preliminary report. Eye $1987 ; 1: 754-6$. 